\title{
ON THE OCCURRENCE OF A GUM IN ECHINOCARPUS (SLOANEA) AUSTRALIS, BENTH.
}

\author{
By J. H. Maiden, F.L.S., \&c.
}

This fine tree, usually known as "Maiden's blush" on account of the colour of its timber, belongs to the Natural Order Tiliaceæ, closely allied, of course, to the Sterculiaceæ and Malvaceæ, many of whose species yield gums.

The Tiliaceæ are also all more or less mucilaginous, but I cannot trace the record of a gum having been found on a plant, whether endemic in Australia or not, belonging to this Natural Order. Various Tiliaceous trees have their mucilaginous inner barks utilized in India as demulcents, and doubtless in other parts of the world, while that of an African species (Grewia mollis) is stated by Barter to be used in soups, because of its mucilaginous character.*

The discovery of gum on Echinocarpus australis by Mr. Bäuerlen, collector for the Technological Museum, is therefore of interest.

It was obtained from an old tree about 60 feet high and 3 feet in diameter. The tree was somewhat injured by fire, but appeared otherwise sound. Some younger trees close by, though not having gum on to collect, showed signs that there had been some formerly. The old tree also showed places where the gum had been dissolved or washed away.

The gum reminds one irresistibly of ox-horn. It contracts on drying, forming transverse cracks, at which it breaks with a bright conchoidal fracture. It cuts like horn. It is tough and tasteless

* Masters in Oliver's Flora of Tropical Africa. 
under the teeth. It swells up in cold water to many times its original bulk, the outer portion becoming so transparent that it is difficult to distinguish it in the liquid, the inner portion remaining translucent and whitish. When pressed between the fingers the soaked gum does not feel gelatinous, although slightly adhesive.

In water it does not dissolve entirely on continued boiling, the liquid becoming slightly cloudy, with small filmy particles floating about in it. On acidifying with hydrochloric acid, the cloudiness and the particles alike disappear. The whole of the gum is precipitated when alcohol is added to this acidified solution. If this precipitate be then filtered off, the greater part is soluble in water. The undissolved portion is soluble in potash of $\cdot 1$ per cent., but not in acidified solutions. If the potash solution be acidified with either acetic or hydrochloric acid, a glairy mass results.

It is instructive to compare this gum with Tragacanth and Sterculia gum.*

This gum agrees with Tragacanth in regard to the points given in the table at p. 384 (op. cit.), with the following exceptions:It does not entirely dissolve on prolonged boiling; forms a granular jelly like Sterculia gum on treatment with cold water, while Tragacanth forms a smooth viscid mass under similar circumstances; contains no starch.

It agrees with Tragacanth on the following points:-A yellowish colour with alkalis on heating; formation of the substance denoted by Giraud as pectic acid. $\dagger$ (I have in another place $\ddagger$ commented on the unsatisfactory position of these so-called pectic bodies.)

Conclusion.-Echinocarpus gum appears to occupy an intermediate position between Sterculia gum and Tragacanth, with greater resemblance to the latter.

The specific gravity of the gum is $\hat{i} \cdot 481$.

* See my paper, "Sterculia Gum ; its similarities and dissimilarities to Tragacanth," Pharm. Journ. (3), xx. 381.

+ Pharm. Journ. (3), v. 766.

$\ddagger$ Chem. and Drugg. of Austral., Feb., 1890. 
Its composition may be stated as follows :-

Soluble in cold water (arabin) .............. 12.05

Soluble in $1 \%$ soda (metarabin); yields arabin on precipitation with alcohol...... $39 \cdot 8$

Vegetable mucilage of Dragendorff; insoluble in $\cdot 1 \%$ acid, $\cdot 1 \%$ soda solution, but soluble in potash solution ............... 20.91

Water....................................... 18.73

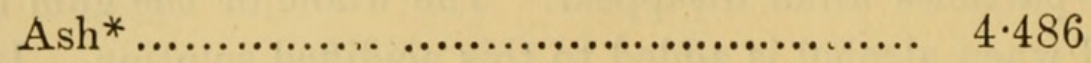

$95 \cdot 976$

Composition of the Ash.

Soluble in water :-

Potassium sulphate........................ $\quad 436$

Insoluble portion :-

Calcium carbonate $\dagger$. $3 \cdot 769$
$\cdot 281$

Magnesium carbonate................ $\cdot 281$

Alumina............................. trace

Ferric oxide.

Total

* Placed in percentage composition for convenience.

† Probably originally existing as oxalate, as calcium oxalate was found in the original gum. 


\section{$2 \mathrm{BHL}$ Biodiversity Heritage Library}

Maiden, J. H. 1891. "On the occurrence of a gum in Echinocarpus (Sloanea) australis, Benth." Proceedings of the Linnean Society of New South Wales 6, 140-142. https://doi.org/10.5962/bhl.part.29882.

View This Item Online: https://www.biodiversitylibrary.org/item/30437

DOI: https://doi.org/10.5962/bhl.part.29882

Permalink: https://www.biodiversitylibrary.org/partpdf/29882

\section{Holding Institution}

MBLWHOI Library

\section{Sponsored by}

MBLWHOI Library

\section{Copyright \& Reuse}

Copyright Status: NOT_IN_COPYRIGHT

This document was created from content at the Biodiversity Heritage Library, the world's largest open access digital library for biodiversity literature and archives. Visit BHL at https://www.biodiversitylibrary.org. 